\title{
Growth Performance, Carcass and Organ Characteristics of Pullets Fed Plantain Ash Supplemented Commercial Diets
}

\author{
Chinwe M. Nwogu' ${ }^{a, *}$, R. K. Nwogu ${ }^{b}$, I. F. Etuk ${ }^{a}$, I. C. Okoli ${ }^{a}$, \& F. N. Madubuike \\ ${ }^{a}$ Tropical Animal Health and Production Research Laboratory, Department of Animal Science and Technology, \\ Federal University of Technology \\ PMB 1526, Owerri, Imo State, Nigeria \\ ${ }^{b}$ Department of Animal Nutrition and Forage Science, Michael Okpara University of Agriculture \\ Umudike, Abia State, Nigeria \\ 'Department of Animal Science and Fisheries, Imo State University \\ PMB 2000, Owerri, Imo State, Nigeria \\ (Received 11-10-2013; Reviewed 25-11-2013; Accepted 12-02-2014)
}

\begin{abstract}
The main objective of this study was to compare the effects of different plantain ash sources (plantain root base ash (PRA) and plantain stalk ash (PSA) supplementation on the performance of pullets fed commercial diets. Ninety six Isa brown pullets aged 15 weeks were therefore used to assess the effect of supplementing commercial diets with plantain root base (PRA) and stalk ashes (PSA) on growth performance, carcass and organ characteristics of pullets during 4 weeks before point of laying (19 weeks of age) and 6 weeks of laying period ( 25 weeks of age). The pullets were divided into two groups of 48 each for supplementation with either PSA or PRA. Each group was divided into four groups of 12, which were further replicated 3 times with 4 birds per replicate in a completely randomized design. At each developmental stage, the feed offered to the birds was supplemented with 0 (control), 1, 2, and $3 \mathrm{~g} / \mathrm{kg}$ body weight of PSA or PRA. One g/ $\mathrm{kgBW}$ of PRA supplementation elicited observable growth performance effects on the birds, while for PSA it was $2 \mathrm{~g} / \mathrm{kgBW}$. The $2 \mathrm{~g} / \mathrm{kgBW}$ PSA supplemented birds gained significantly $(\mathrm{P}<0.05)$ more weight than the other groups except the control, which consumed significantly $(\mathrm{P}<0.05)$ more feed. At point of laying, the $1 \mathrm{~g} / \mathrm{kgBW}$ PRA group recorded significantly $(\mathrm{P}<0.05)$ higher body weight and weight gain than the control. Plantain root base ash affected dressing percentage significantly $(\mathrm{P}<0.05)$ resulting in higher thigh weights, while organ weights decreased with increasing ash supplementation levels. Plantain ash therefore has positive effect on growth and edible carcass cut.
\end{abstract}

Key words: plantain ash, pullets, feed, carcass

\section{ABSTRACT}

Penelitian ini bertujuan untuk membandingkan pengaruh suplementasi sumber abu yang berbeda dari pohon pisang (sumber abu dari akar pisang (PRA) dan sumber abu dari batang pisang (PSA) terhadap performa ayam petelur dara (pullet) yang diberi pakan komersial. Sebanyak 96 ekor pullet strain Isa brown berumur 15 minggu digunakan untuk melihat pengaruh pakan komersial yang disuplementasi PRA dan PSA terhadap pertumbuhan, karkas, dan karakteristik organ selama 4 minggu sebelum waktu bertelur (usia 19 minggu) dan 6 minggu selama masa bertelur (usia 25 minggu). Pullet dibagi ke dalam 2 kelompok, masing-masing sebanyak 48 ekor, untuk disuplementasi dengan PSA atau PRA. Masing-masing kelompok dibagi lagi menjadi 4 kelompok (masing-masing 12 ekor) yang diulang 3 kali dengan 4 ekor ayam per ulangan dalam rancangan acak lengkap. Pakan yang diberikan pada setiap tahap perkembangan disuplementasi PSA atau PRA dengan level 0 (kontrol), 1, 2, dan 3 $\mathrm{g} / \mathrm{kg}$ bobot badan. Suplementasi PRA $1 \mathrm{~g} / \mathrm{kgBB}$ menunjukkan pengaruh terhadap performa ayam, sedangkan untuk PSA sebesar 2 g/kgBB. Suplementasi 2 g/kgBB PSA nyata $(P<0,05)$ meningkatkan BB ayam dibanding kelompok lain, kecuali kontrol $(\mathrm{P}<0,05)$. Pada masa bertelur, kelompok yang diberi 1g/ kgBW PRA nyata $(P<0,05)$ menghasilkan bobot badan dan pertambahan bobot badan yang lebih tinggi dibanding kontrol. Sumber abu dari akar pisang menghasilkan bobot paha yang lebih tinggi $(\mathbf{P}<0,05)$, sedangkan bobot organ menurun dengan meningkatnya level suplementasi abu. Dapat disimpulkan bahwa abu dari pohon pisang memiliki efek positif terhadap pertumbuhan dan bobot karkas.

Kata kunci: abu dari tanaman pisang, pullets, pakan, karkas

*Corresponding author:

E-mail: marychinwe50@yahoo.com 


\section{INTRODUCTION}

Optimum nutrition occurs when the bird is offered the correct mix of macro and micro nutrients in the feed and is able to utilize those nutrients for its growth, health, reproduction and survival. Proper nutrition could encourage mediocre biological types to reach genetic potential and may even alleviate the negative effects of a harsh physical environment (Nwogu et al., 2012).

A number of studies have been carried out on the utilization of plant ashes in agriculture. Plant ashes have been used to deactivate tannins in Acacia cynophylla foliage to improve digestion by Barbarine sheep (Salem et al., 2005). It has also been used as mineral supplement for growing lambs (Maleana, 1998). Though it has not been used for supplementation in poultry, Ochetim (1998), suggested the use of plant ash as a source of minerals for poultry. In a very recent study, Oso et al. (2011) used wood ash as calcium source in broiler production and concluded that it is deleterious to bone development. However, plantain ash which is the inorganic residue derived after the combustion of all organic components of plantain root base and stalk has recently been shown to enhance mineral absorption from the gastrointestinal tracts of pullets (Okoli et al., 2013). Coconut shell ash also acts as a mild argonist of reproductive organ development and sex hormone release in pubertal rabbits (Iwu et al., 2013).

After the harvest of plantain and banana fruits, their stalk are often undervalued and considered as waste material, creating a disposal problem (Anirudhan \& Shibi, 2007). However, previous studies on some plants wastes including peels and stalk of the tropical plantain Musa paradisiaca have shown them to be rich in elemental composition (Selema \& Farago, 1996; Nwogu et al., 2012). Ash obtained from complete ashing of plantain root base and stalk materials could therefore be used to supplement commercial feeds produced in Nigeria which have been shown to be generally low in elemental composition (Okoli et al., 2013).

This study was therefore designed to investigate the effects of plantain ash supplementation on the growth performance, carcass and organ characteristics of pullets fed commercial diets.

\section{MATERIALS AND METHODS}

\section{Ash Preparation and Analyses}

The stalk of mature plantain plants from which the fruits had been harvested and their root base were collected, cut into pieces, sun dried and ashed using a developed customized method to produce customized plantain stalk (PSA) and root base (PRA) ashes (Nwogu et al., 2012). These were analyzed for their concentrations of nickel, chromium, lead, iron, copper, zinc, cobalt, calcium, magnesium, sodium, manganese, potassium and cadmium using the atomic absorption spectrophotometer (Table 1).

\section{Experimental Birds and Feeds}

Ninety six Isa Brown pullets aged 15 wk were divided into two groups of 48 birds each and used to assess the effect of PSA and PRA supplementation of commercial grower and layer rations (Top Feeds ${ }^{\circledR}$, Sapele, Nigeria) on growth performance, carcass and organ characteristics of pullets during $4 \mathrm{wk}$ before point of laying (19 wk of age) and a further $6 \mathrm{wk}$ of laying period (25 wk of age). The commercial feeds were also analyzed for their mineral concentrations and values (Table 2) as well as the chemical compositions (Table 3).

Each group of birds was divided into four groups of 12 which were further replicated 3 times with 4 birds per replicate in a completely randomized design (CRD). At each development stage, the feed offered to the birds was supplemented with $\mathrm{O}$ (control), 1, 2, and $3 \mathrm{~g} / \mathrm{kg}$ body weight $(\mathrm{BW})$ of ash.

\section{Growth Performance Determination}

Growth performances at each development stage were determined. The initial live weights of the birds were recorded at the beginning of the experiment and subsequent weighing was done weekly on individual basis in the morning hours (7-9 am). Weight gain was obtained by subtracting initial live weight from the live weight at the $5^{\text {th }}$ and $10^{\text {th }}$ wk respectively of the experiment, which corresponded to the $19^{\text {th }}$ and $25^{\text {th }}$ wk of age. Data on feed intake was determined by difference between the quantity offered and the quantity of left-over each day. Feed conversion ratio (FCR) was determined by dividing total feed intake by body weight gain. The feed efficiency was derived as the inverse of the FCR (Esonu, 2006).

Table 1. Ash mineral analyses of the laboratory and custom produced ashes from stalk (PSA) and root (PRA) (mg/ $100 \mathrm{~g})$

\begin{tabular}{|c|c|c|c|c|}
\hline Minerals & $\begin{array}{c}\text { Lab } \\
\text { produced } \\
\text { PSA }\end{array}$ & $\begin{array}{c}\text { Lab } \\
\text { produced } \\
\text { PRA }\end{array}$ & $\begin{array}{c}\text { Custom } \\
\text { produced } \\
\text { PSA }\end{array}$ & $\begin{array}{c}\text { Custom } \\
\text { produced } \\
\text { PRA }\end{array}$ \\
\hline $\mathrm{Cu}$ & 120.00 & 91.00 & 0.010 & 0.007 \\
\hline $\mathrm{Ni}$ & 5.00 & 2.00 & 0.254 & 0.107 \\
\hline $\mathrm{Fe}$ & 5.00 & 5.00 & 2.50 & 2.70 \\
\hline $\mathrm{Zn}$ & 4.00 & 4.00 & 0.10 & 0.90 \\
\hline $\mathrm{Pb}$ & 63.00 & 13.00 & 0.014 & 0.014 \\
\hline $\mathrm{Mg}$ & 140.00 & 140.00 & 6.90 & 6.60 \\
\hline $\mathrm{Ca}$ & 190.00 & 260.00 & 191.00 & 84.00 \\
\hline $\mathrm{Na}$ & 0.09 & 0.08 & 0.003 & 0.004 \\
\hline K & $<0.001$ & $<0.001$ & 0.63 & 0.58 \\
\hline $\mathrm{Mn}$ & 4.00 & 4.00 & 3.80 & 1.60 \\
\hline $\mathrm{Cd}$ & $<0.1$ & $<0.1$ & 0.013 & 0.011 \\
\hline $\mathrm{Cr}$ & 0.23 & 0.49 & 0.09 & 0.27 \\
\hline Co & 0.003 & 0.007 & $0.10^{\mathrm{a}}$ & 0.13 \\
\hline As & $<0.001$ & $<0.001$ & BDL & BDL \\
\hline $\mathrm{pH}$ & 12.40 & 12.50 & - & - \\
\hline
\end{tabular}

Note: BDL= Below Detection Level; $(-)=$ not tested. 
Table 2. Mineral concentration in experimental commercial diets $(\mathrm{mg} / 100 \mathrm{~g})$

\begin{tabular}{ccccc}
\hline \multirow{2}{*}{ Minerals } & \multirow{2}{*}{$\begin{array}{c}\text { Grower } \\
\text { mash }\end{array}$} & \multirow{2}{*}{$\begin{array}{c}\text { Layer } \\
\text { mash }\end{array}$} & \multicolumn{2}{c}{ SON recommended } \\
\cline { 4 - 5 } & & Grower & Layer \\
\hline $\mathrm{Ca}$ & 192 & 244 & 1000 & 3500 \\
$\mathrm{Mg}$ & 20 & 52 & 47.50 & 52.50 \\
$\mathrm{~K}$ & 0.47 & 0.44 & 375 & 375 \\
$\mathrm{Na}$ & 1.00 & 1.10 & 225 & 225 \\
$\mathrm{P}$ & 0.05 & 0.047 & 400 & 450 \\
$\mathrm{Fe}$ & 0.04 & 0.07 & 9.25 & 5.50 \\
$\mathrm{Mn}$ & 1.41 & 1.13 & 3.50 & 5.50 \\
$\mathrm{Zn}$ & 1.40 & 1.70 & 4.50 & 3.50 \\
$\mathrm{Cu}$ & 0.26 & 0.14 & 0.95 & 0.95 \\
$\mathrm{Se}$ & - & - & 0.015 & 0.015 \\
$\mathrm{I}$ & & & 0.035 & 0.0525 \\
$\mathrm{~Pb}$ & 0.00 & 0.73 & - & - \\
$\mathrm{Cd}$ & 0.002 & 0.002 & - & - \\
\hline
\end{tabular}

Note: $\mathrm{SON}=$ Standard Organization of Nigeria; $(-)=$ not tested.

Table 3. Nutrient compositions of the commercial diets used

\begin{tabular}{lrrr}
\hline Variable & $\begin{array}{c}\text { Chick } \\
\text { mash }\end{array}$ & $\begin{array}{c}\text { Grower } \\
\text { mash }\end{array}$ & $\begin{array}{c}\text { Layer } \\
\text { mash }\end{array}$ \\
\hline Crude protein(\%) & 21.00 & 16.00 & 16.50 \\
Fats / oil (\%) & 6.00 & 5.00 & 5.00 \\
Crude fiber (\%) & 5.00 & 7.00 & 6.00 \\
Calcium (\%) & 1.00 & 1.00 & 3.80 \\
Available phosphorus (\%) & 0.45 & 0.45 & 0.45 \\
Lysine (\%) & 1.00 & 0.75 & 0.80 \\
Methionine (\%) & 0.50 & 0.36 & 0.34 \\
Salt (min) & 0.30 & 0.30 & 0.30 \\
Minimum metabolizable & 2800 & 2450 & 2500 \\
energy (Kcal/kg) & & & \\
Net weight (kg) & 25.00 & 25.00 & 25.00 \\
\hline
\end{tabular}

\section{Carcass and Organ Characteristics Determination}

At week five of the study, when the experimental birds were one week into laying, a bird from each replicate of the various treatments was randomly selected, weighed, slaughtered after fasting them overnight and used to determine carcass and organ weight characteristics. The birds were slaughtered by severing the jugular vein and allowed to bleed thoroughly according to the method outlined by Odunsi et al. (1999). Thereafter carcasses were defeathered, cleaned, dissected and eviscerated. The head, shanks, intestinal contents and organs were removed. The remaining carcass was weighed and expressed as a percentage of the live weight to obtain the dressed weight percentage. The thigh, breast muscle, wings, head and legs were weighed and expressed as percentage of the live weight. The organs which include the liver, neck, ovary/oviduct, intestine, proventriculus, gizzard, spleen and heart were weighed respectively and expressed as percentage of the live weight.

\section{Data Analysis}

Data collected on the different parameters was subjected to statistical analysis using analysis of variance (ANOVA) (Steel \& Torrie, 1995). Statistical differences among means were separated using the Least Significant Difference (LSD) method (SAS, 2000).

\section{RESULTS AND DISCUSSION}

\section{Experimental Diets}

Data in Table 2 shows the mineral composition of the commercial grower and layer rations used in the study and their comparisons with the Standard Organization of Nigeria recommended values (SON, 2003). These results and earlier ones from our station (Okoli et al., 2013) highlighted the inadequacy of mineral content of commercial poultry feeds produced in Nigeria.

The supplementation of extra mineral elements when feeding these commercial rations is therefore desirable, especially minerals from organic sources such as plant ashes. Generally, organic sources of the trace minerals have been reported to have greater bioavailability than inorganic sources because they prevent phytate from binding to the metal in the gastrointestinal tract, while still being water soluble, thus facilitating mineral uptake in the small intestine (Kidd et al., 1996; Cao et al., 2000). Thus, it is probable that the plant ash would not only provide readily bio-available minerals to the birds, but may also improve the intestinal uptake of earth mineral sources from the ingesta as recently reported in rabbits fed coconut shell ash in our station (Iwuh et al., 2013).

\section{Growth Performance}

The growth performance results of the PSA and PRA supplemented pullets were shown in Tables 4 and 5 respectively. At point of laying and $25 \mathrm{wk}$ of age, the control (T1) birds returned higher final weights reflecting their higher initial weights (Table 4). However, the weight gain recorded by $\mathrm{T} 3$ at this period was superior to the others and was significantly $(\mathrm{P}<0.05)$ higher than those of T2 and T4, but similar to T1 $(\mathrm{P}>0.05)$. Again, at point of lay and $25 \mathrm{wk}$ of age, the control birds consumed more feed than any of the PSA supplemented groups. This was followed by T2 that consumed significantly more feed $(\mathrm{P}<0.05)$ than the $\mathrm{T} 4$ at $25 \mathrm{wk}$ of age. At both periods again, the T3 returned superior feed conversion ratio to all the other groups, while the most inferior result was recorded in the T4 group. Feed efficiency results followed similar trends. Among the PRA supplemented birds, R1 and R2 groups returned significantly higher weight gains $(\mathrm{P}<0.05)$ than $\mathrm{R} 3$ at both point of lay and 25 weeks of age (Table 2). While the control and R2 birds had similar weight gains at point of lay $(\mathrm{P}>0.05)$, 
at 25 wk of age, the R2 birds had out grown the control birds and had gained significantly more weight $(\mathrm{P}<0.05)$. The R3 birds had also at this period gained significantly more weight than the control $(\mathrm{P}<0.05)$ even though they remained lighter than the control group (Table 5).

The FCR results showed again the superiority of the R2 birds in converting food with 4.352 ratios returned for this group being significantly superior to the range of 8.212 to 16.481 returned for others at point of lay. These figures closed -up to a range of 5.708-7.514 at 25 wk of age with the control birds giving the most inferior performance. The feed efficiency results followed similar trends.

These present results showed that PRA may elicit better growth performance results than the PSA since it required about $1 \mathrm{~g} / \mathrm{kg} \mathrm{BW}$ (R2) supplementation to elicit observable effects (weight gain and FCR) in the ex- perimental birds, while for PSA it was $2 \mathrm{~g} / \mathrm{kg}$ BW. There is the need to test the materials in meat type broiler to evaluate these effects.

The feed conversion ratios obtained in this study were very high compared to those reported for broilers (3.88) by Uchegbu et al. (2009a and 2009b). This is expected since genetically pullets are not selected to lay down flesh but to convert feed into eggs. Excessive weight at point of lay will usually result to poor laying performance (Oluyemi \& Roberts, 1979).

Anyanwu et al. (2008) however reported FCR range of 1.99 to 2.11 in point of lay birds fed different combinations of cassava root meal and bambara groundnut offal. Udedibie et al. (2012) also reported FCRs of 3.22 and 3.76 in laying birds fed cassava products starting from their $8^{\text {th }}$ mo of lay up to $12 \mathrm{wk}$ of feeding. In the present study, the experimental birds were fed commercial ra-

Table 4. Growth performance of pullets supplemented with plantain stalk ash (PSA)

\begin{tabular}{|c|c|c|c|c|c|}
\hline \multirow{2}{*}{ Variable } & \multicolumn{4}{|c|}{ Treatments } & \multirow{2}{*}{ SEM } \\
\hline & $\mathrm{T} 1$ & $\mathrm{~T} 2$ & $\mathrm{~T} 3$ & $\mathrm{~T} 4$ & \\
\hline Initial weight (g) (15 wk of age) & $1250.00^{\mathrm{a}}$ & $1250.00^{\mathrm{ab}}$ & $1150.00^{\mathrm{b}}$ & $1242.00^{\mathrm{ab}}$ & 24.4062 \\
\hline Weight (g) at point of laying (19 wk) & $1580.00^{\mathrm{a}}$ & $1517.00^{\mathrm{ab}}$ & $1500.00^{\mathrm{b}}$ & $1467.00^{\mathrm{b}}$ & 23.7241 \\
\hline Weight gain $(\mathrm{g})$ at point of laying & $330.00^{\mathrm{ab}}$ & $267.00^{\mathrm{b}}$ & $350.00^{\mathrm{a}}$ & $225.00^{\mathrm{b}}$ & 28.7489 \\
\hline Final weight at $25 \mathrm{wk}$ & $1800.00^{\mathrm{a}}$ & $1780.00^{\text {ac }}$ & $1792.00^{\mathrm{a}}$ & $1750.00^{\mathrm{bc}}$ & 10.9658 \\
\hline Final weight gain at $25 \mathrm{wk}$ & $550.00^{\mathrm{b}}$ & $530.00^{\mathrm{b}}$ & $642.00^{\mathrm{a}}$ & $508.00^{\mathrm{b}}$ & 29.4434 \\
\hline Cumulative feed intake (g) at pt of laying (19 wk) & $2710.00^{\mathrm{a}}$ & $2620.00^{\mathrm{ab}}$ & $2520.00^{\mathrm{b}}$ & $2480.00^{\mathrm{b}}$ & 51.7003 \\
\hline Cumulative feed intake (g) at $25 \mathrm{wk}$ & $4132.80^{\mathrm{a}}$ & $4119.00^{\text {ac }}$ & $4099.20^{\text {bc }}$ & $4067.40^{\mathrm{b}}$ & 14.1880 \\
\hline FCR at point of laying & $8.212^{\mathrm{bc}}$ & $9.813^{\mathrm{ac}}$ & $7.200^{\mathrm{b}}$ & $11.022^{\mathrm{a}}$ & 0.8463 \\
\hline FCR at $25 \mathrm{wk}$ & $7.514^{\mathrm{a}}$ & $7.772^{\mathrm{a}}$ & $6.385^{\mathrm{b}}$ & $8.007^{\mathrm{a}}$ & 0.3592 \\
\hline Feed efficiency at point of laying (\%) & $12.18^{\mathrm{ac}}$ & $10.19^{\mathrm{bc}}$ & $13.89^{a}$ & $9.07^{\mathrm{b}}$ & 1.0678 \\
\hline Feed efficiency at $25 \mathrm{wk}(\%)$ & $13.31^{\mathrm{b}}$ & $12.87^{\mathrm{b}}$ & $15.66^{\mathrm{a}}$ & $12.49^{\mathrm{b}}$ & 0.7124 \\
\hline
\end{tabular}

Note: Means in the same row with different superscript differ significantly $(\mathrm{P}<0.05)$. T1= Feed supplemented with $0 \mathrm{~g} / \mathrm{kg}$ BW of PSA (control), T2= Feed supplemented with $1 \mathrm{~g} / \mathrm{kg}$ BW of PSA, T3= Feed supplemented with $2 \mathrm{~g} / \mathrm{kg}$ BW of PSA, T4= Feed supplemented with $3 \mathrm{~g} / \mathrm{kg}$ BW of PSA.

Table 5. Growth performance of pullets supplemented with plantain root base ash (PRA)

\begin{tabular}{|c|c|c|c|c|c|}
\hline \multirow{2}{*}{ Variable } & \multicolumn{4}{|c|}{ Treatments } & \multirow{2}{*}{ SEM } \\
\hline & R1 & $\mathrm{R} 2$ & R3 & $\mathrm{R} 4$ & \\
\hline Initial weight (g) (15 wk of age) & $1250.00^{\mathrm{a}}$ & $1225.00^{\mathrm{ab}}$ & $1192.00^{\mathrm{b}}$ & $1217.00^{\mathrm{ab}}$ & 11.9512 \\
\hline Weight at point of laying (19 wk) & $1580.00^{\mathrm{a}}$ & $1600.00^{\mathrm{a}}$ & $1350.00^{\mathrm{b}}$ & $1450.00^{\mathrm{ab}}$ & 58.6657 \\
\hline Weight gain (g) at point of laying (19 wk) & $330.00^{\mathrm{a}}$ & $375.00^{\mathrm{a}}$ & $158.00^{\mathrm{b}}$ & $233.00^{\mathrm{ab}}$ & 48.7117 \\
\hline Final weight at $25 \mathrm{wk}$ & $1800.00^{\mathrm{b}}$ & $1850.00^{\mathrm{a}}$ & $1781.00^{\mathrm{b}}$ & $1785.00^{\mathrm{b}}$ & 15.8692 \\
\hline Final weight gain & $550.00^{\mathrm{b}}$ & $625.00^{\mathrm{a}}$ & $589.00^{\mathrm{a}}$ & $568.00^{\mathrm{b}}$ & 16.1090 \\
\hline Cumulative feed intake (g) at point of laying (19 wk) & $2710.00^{\mathrm{a}}$ & $2720.00^{\mathrm{a}}$ & $2604.00^{\mathrm{b}}$ & $2472.00^{\mathrm{b}}$ & 54.3316 \\
\hline Cumulative feed intake (g) at $25 \mathrm{wk}$ & $4132.80^{\mathrm{a}}$ & $4200.00^{\mathrm{a}}$ & $4080.00^{\mathrm{ab}}$ & $3810.00^{\mathrm{b}}$ & 85.5014 \\
\hline FCR at point of laying & $8.212^{b}$ & $4.352^{\mathrm{b}}$ & $16.481^{\mathrm{a}}$ & $10.609^{a b}$ & 2.5406 \\
\hline FCR at $25 \mathrm{wk}$ & $7.514^{\mathrm{a}}$ & $6.720^{\mathrm{b}}$ & $6.927^{\mathrm{b}}$ & $6.708^{\mathrm{b}}$ & 0.1890 \\
\hline Feed efficiency at point of laying (\%) & $12.18^{\mathrm{ab}}$ & $22.97^{a}$ & $6.07^{\mathrm{b}}$ & $9.43^{\mathrm{b}}$ & 3.6559 \\
\hline Feed efficiency at $25 \mathrm{wk}(\%)$ & $13.31^{\mathrm{b}}$ & $14.88^{\mathrm{a}}$ & $14.44^{\mathrm{a}}$ & $14.91^{\mathrm{a}}$ & 0.3740 \\
\hline
\end{tabular}

Note: Means in the same row with different superscript differ significantly $(\mathrm{P}<0.05)$. R1= Feed supplemented with $0 \mathrm{~g} / \mathrm{kg}$ BW of PRA (control), R2= Feed supplemented with $1 \mathrm{~g} / \mathrm{kg}$ BW of PRA, R3= Feed supplemented with $2 \mathrm{~g} / \mathrm{kg} \mathrm{BW}$ of PRA, R4= Feed supplemented with $3 \mathrm{~g} / \mathrm{kg}$ BW of PRA. 
tions thus indicating that the FCR and FE data obtained may be reflecting the actual field or farm experiences in the study area.

\section{Carcass Characteristics}

The carcass characteristics of the ash supplemented laying pullets are shown in Table 6 and 7. The PSA supplemented birds (Table 6) yielded dressing percentage range of 57.00-59.33, while PRA birds yielded a range of $52.24 \%-63.75 \%$. Even though there were significant differences $(\mathrm{P}<0.05)$ between the values obtained among the PSA supplemented birds, the values were close enough to suggest limited treatment effects on dressing percentage.

In the case of the PRA treated birds (Table 7), R2 birds yielded significantly lower $(\mathrm{P}<0.05)$ value than $\mathrm{R} 3$ and $\mathrm{R} 4$ and the range of difference suggests a high treatment effect of PRA on dressing percentage. This PRA effect was driven by the corresponding significantly $(\mathrm{P}<0.05)$ higher percentage thigh weights of R3 (21.77) and R4 (21.08) than R1 and R2 that ranged 16.18 to $17.94 \%$. The same effect was observed in percentage thigh values of PSA even though milder. The control birds with the second highest percentage dressed weight $(59.00 \%)$ yielded the lowest percentage thigh weight which was significantly $(\mathrm{P}<0.05)$ lower than T4 $(20.00 \%)$. Generally, R4 that recorded the lowest live weight among the PRA treated birds recorded the highest percentage values for all the parameters measured. This means that while the $3 \mathrm{~g} / \mathrm{kg}$ BW treated birds did not grow as fast as the other treatment groups and the control; they however, yielded superior carcass parts in relation to their weights.

The earlier reported growth performance results (Table 4-5) showed that the birds on $3 \mathrm{~g} / \mathrm{kg} \mathrm{BW}$ (T4 and R4) also recorded the least feed intake, weight gain, feed conversion ratio and feed efficiency. This finding shows that growth performance results need to be related to carcass yield to determine the actual overall effects of a feed supplement or ingredient on poultry productivity. Uchegbu et al. (2004) reported percentage breast muscle yield of $10.6 \%-17.6 \%$ in finisher broilers feed graded levels of raw Napoleona imperials seed meal with the upper value being the control. Result of $13.33 \%-18.67 \%$ for PSA treated birds and $14.82 \%-17.75 \%$ for PRA treated birds, with the upper values belonging to the $3 \mathrm{~g} / \mathrm{kg} \mathrm{BW}$ supplementation suggests that PSA and PRA treatments could cause the yielding of better carcass parts in meat type poultry. This needs to be validated.

Table 6. Carcass characteristics of birds at 5 weeks of feeding plantain stalk ash (PSA)

\begin{tabular}{|c|c|c|c|c|c|}
\hline \multirow{2}{*}{ Variable } & \multicolumn{4}{|c|}{ Treatments } & \multirow{2}{*}{ SEM } \\
\hline & $\mathrm{T} 1$ & $\mathrm{~T} 2$ & $\mathrm{~T} 3$ & $\mathrm{~T} 4$ & \\
\hline LW (g) & $1600.00^{\mathrm{a}}$ & $1500.00^{\mathrm{b}}$ & $1500.00^{\mathrm{b}}$ & $1500.00^{\mathrm{b}}$ & 25.00 \\
\hline Dressed weight (\%) & $59.00^{\mathrm{ab}}$ & $57.00^{c}$ & $59.20^{\mathrm{a}}$ & $57.33^{\mathrm{bc}}$ & 0.564 \\
\hline Thigh (\%) & $17.938^{\mathrm{b}}$ & $19.20^{\mathrm{ab}}$ & $18.93^{\mathrm{ab}}$ & $20.00^{\mathrm{a}}$ & 0.425 \\
\hline Breast muscle (\%) & $16.188^{\mathrm{ab}}$ & $15.00^{\mathrm{b}}$ & $13.33^{\mathrm{b}}$ & $18.67^{a}$ & 1.12 \\
\hline Wings (\%) & $6.500^{\mathrm{b}}$ & $6.333^{\mathrm{b}}$ & $8.200^{\mathrm{a}}$ & $7.467^{\mathrm{ab}}$ & 0.437 \\
\hline Head (\%) & $2.688^{\mathrm{ab}}$ & $2.733^{\mathrm{a}}$ & $2.533^{\mathrm{bc}}$ & $2.467^{\mathrm{bc}}$ & 0.063 \\
\hline Legs (\%) & $3.500^{\mathrm{b}}$ & $3.667^{\mathrm{a}}$ & $3.667^{\mathrm{a}}$ & $3.600^{\mathrm{ab}}$ & 0.04 \\
\hline
\end{tabular}

Note: Means in the same row with different superscript differ significantly $(\mathrm{P}<0.05)$. T1= Feed supplemented with $0 \mathrm{~g} / \mathrm{kg} \mathrm{BW}$ of PSA (control), T2= Feed supplemented with $1 \mathrm{~g} / \mathrm{kg}$ BW of PSA, T3= Feed supplemented with $2 \mathrm{~g} / \mathrm{kg}$ BW of PSA, T4= Feed supplemented with $3 \mathrm{~g} / \mathrm{kg}$ BW of PSA.

Table 7. Carcass characteristics of birds at 5 weeks of feeding plantain root base ash (PRA)

\begin{tabular}{lrrrrr}
\hline \multirow{2}{*}{ Variable } & \multicolumn{3}{c}{ Treatments } & \multicolumn{2}{c}{ SEM } \\
\cline { 2 - 5 } & \multicolumn{1}{c}{ R1 } & \multicolumn{1}{c}{ R2 } & \multicolumn{1}{c}{ R3 } & \multicolumn{2}{c}{ R4 } \\
\hline LW (g) & $1600.00^{\mathrm{ab}}$ & $1700.00^{\mathrm{a}}$ & $1300.00^{\mathrm{bc}}$ & $1200.00^{\mathrm{c}}$ & 119.00 \\
Dressed weight (\%) & $59.00^{\mathrm{ab}}$ & $52.235^{\mathrm{ab}}$ & $63.308^{\mathrm{a}}$ & $63.750^{\mathrm{a}}$ & 2.67 \\
Thigh (\%) & $17.938^{\mathrm{ab}}$ & $16.176^{\mathrm{b}}$ & $21.769^{\mathrm{a}}$ & $21.083^{\mathrm{a}}$ & 1.32 \\
Breast muscle (\%) & $16.188^{\mathrm{ab}}$ & $14.824^{\mathrm{b}}$ & $16.615^{\mathrm{ab}}$ & $17.750^{\mathrm{a}}$ & 0.604 \\
Wings (\%) & $6.500^{\mathrm{bc}}$ & $5.941^{\mathrm{c}}$ & $8.000^{\mathrm{ab}}$ & $8.417^{\mathrm{a}}$ & 0.591 \\
Head (\%) & $2.688^{\mathrm{b}}$ & $2.765^{\mathrm{b}}$ & $2.692^{\mathrm{b}}$ & $3.417^{\mathrm{a}}$ & 0.176 \\
Legs (\%) & $3.500^{\mathrm{ab}}$ & $2.941^{\mathrm{b}}$ & $3.692^{\mathrm{a}}$ & $4.083^{\mathrm{a}}$ & 0.238 \\
Neck (\%) & $4.500^{\mathrm{ab}}$ & $3.933^{\mathrm{b}}$ & $5.000^{\mathrm{a}}$ & $4.467^{\mathrm{ab}}$ & 0.218 \\
\hline
\end{tabular}

Note: Means in the same row with different superscript differ significantly $(\mathrm{P}<0.05)$. R1= Feed supplemented with $0 \mathrm{~g} / \mathrm{kg} \mathrm{BW}$ of $\mathrm{PRA}$ (control), R2= Feed supplemented with $1 \mathrm{~g} / \mathrm{kg}$ BW of PRA, R3= Feed supplemented with $2 \mathrm{~g} / \mathrm{kg} \mathrm{BW}$ of PRA, R4= Feed supplemented with $3 \mathrm{~g} / \mathrm{kg}$ BW of PRA. 


\section{Organ Characteristics}

The percentage organ weight characteristics of the plantain ash supplemented birds are presented in Table 8 and 9 . Generally, percentages of the parameters measured decreased with increasing supplementation levels of both the PSA and PRA. This is again indicative of the fact that the percentage contributions of these organ parts to the live weights of the birds were decreasing at the expense of the carcass parts and not necessarily their actual weights (Baley \& Teeter, 1996). The exception to this trend was observed in the gizzard values that increased above control value at T2 and T3 for PSA and R3 and R4 for PRA supplementations respectively. These results are probably suggestive of the increased grittiness of the ash supplemented diets making the gizzard to perform more work (Esonu, 2006). The ovary and oviductal morphometric developments observed in this study implied that in both PSA and PRA treated birds; the controls and the $1 \mathrm{~g} / \mathrm{kg} \mathrm{BW}$ supplemented groups are under hormonal influence associated with heavy to moderate laying. The other groups depicted ovary/oviductal development of birds that are yet to begin egg formation and laying.

\section{CONCLUSION}

It requires $1 \mathrm{~g} / \mathrm{kg}$ BW PRA supplementation to elicit observable growth performance effects in the experimental birds, while for PSA it is $2 \mathrm{~g} / \mathrm{kg} \mathrm{BW}$. Observed ovary and oviductal morphometric developments imply that the controls and $1 \mathrm{~g} / \mathrm{kg}$ BW supplemented groups are under hormonal influence associated with heavy to moderate laying. Even though carcass and organ characteristics of experimental animals are usually viewed as morphometric measurements used to determine pathological effects of feeding novel materials to animal, they can also serve as economic indicators to the producers.

\section{REFERENCES}

Anirudhan, T. S. \& I. G. Shibi. 2007. Preparation of a cation exchanger containing carboxy stalk and its utilization as chelating agent. Info Musa 16: 7-9.

Anyanwu, G. A., E. B. Etuk, I. C. Okoli, \& A. B. I. Udedibie. 2008. Performance and egg quality characteristics of layers fed different combinations of cassava root meal and bambara groundnut offal. Asian J. Poult Sci. 2: 36-41. http:// dx.doi.org/10.3923/ajpsaj.2008.36.41

Baley, T. \& R. G. Teeter. 1996. Virginiamycin and caloric den-

Table 8. Organ characteristics of birds at 5 weeks of feeding plantain stalk ash (PSA)

\begin{tabular}{|c|c|c|c|c|c|}
\hline \multirow{2}{*}{ Variable } & \multicolumn{4}{|c|}{ Parameters } & \multirow{2}{*}{ SEM } \\
\hline & $\mathrm{T} 1$ & $\mathrm{~T} 2$ & $\mathrm{~T} 3$ & $\mathrm{~T} 4$ & \\
\hline Liver (\%) & $2.375^{\mathrm{a}}$ & $1.933^{\mathrm{ab}}$ & $1.533^{\mathrm{b}}$ & $1.400^{\mathrm{b}}$ & 0.220 \\
\hline Ovary/Oviduct (\%) & $2.813^{\mathrm{a}}$ & $1.333^{\mathrm{ab}}$ & $0.133^{\mathrm{b}}$ & $0.400^{\mathrm{b}}$ & 0.605 \\
\hline Intestines (\%) & $5.250^{\mathrm{a}}$ & $4.733^{\mathrm{b}}$ & $4.867^{\mathrm{ab}}$ & $4.600^{\mathrm{b}}$ & 0.140 \\
\hline Proventriculus (\%) & $0.500^{\mathrm{ab}}$ & $0.533^{\mathrm{a}}$ & $0.267^{c}$ & $0.333^{\text {bc }}$ & 0.064 \\
\hline Gizzard (\%) & $3.625^{b}$ & $4.000^{\mathrm{a}}$ & $3.733^{\mathrm{ab}}$ & $3.600^{\mathrm{b}}$ & 0.092 \\
\hline Spleen $(\%)$ & $0.188^{\mathrm{b}}$ & $0.200^{\mathrm{a}}$ & $0.200^{\mathrm{a}}$ & $0.200^{\mathrm{a}}$ & 0.003 \\
\hline Heart (\%) & $0.438^{\mathrm{a}}$ & $0.400^{\mathrm{ab}}$ & $0.400^{\mathrm{ab}}$ & $0.333^{\mathrm{b}}$ & 0.022 \\
\hline
\end{tabular}

Note: Means in the same row with different superscript differ significantly $(\mathrm{P}<0.05)$. T1 = Feed supplemented with $0 \mathrm{~g} / \mathrm{kg}$ BW of PSA (control), T2= Feed supplemented with $1 \mathrm{~g} / \mathrm{kg}$ BW of PSA, T3= Feed supplemented with $2 \mathrm{~g} / \mathrm{kg}$ BW of PSA, T4= Feed supplemented with $3 \mathrm{~g} / \mathrm{kg}$ BW of PSA.

Table 9. Organ characteristics of birds at 5 weeks of feeding plantain root base ash (PRA)

\begin{tabular}{lccccc}
\hline \multirow{2}{*}{ Variable } & \multicolumn{2}{c}{ Parameters } & \multirow{2}{*}{ SEM } \\
\cline { 2 - 5 } & R1 & R2 & R3 & R4 & \\
\hline Liver (\%) & $2.375^{\mathrm{a}}$ & $1.706^{\mathrm{b}}$ & $1.692^{\mathrm{b}}$ & $1.333^{\mathrm{b}}$ & 0.220 \\
Neck (\%) & $4.500^{\mathrm{bc}}$ & $4.118 \mathrm{c}$ & $5.538^{\mathrm{ab}}$ & $5.833^{\mathrm{a}}$ & 0.409 \\
Ovary/Oviduct (\%) & $2.813^{\mathrm{a}}$ & $2.176^{\mathrm{ab}}$ & $0.231^{\mathrm{bc}}$ & $0.042^{\mathrm{c}}$ & 0.694 \\
Intestines (\%) & $5.250^{\mathrm{ab}}$ & $4.529^{\mathrm{c}}$ & $5.615^{\mathrm{a}}$ & $4.833^{\mathrm{bc}}$ & 0.238 \\
Proventriculus (\%) & $0.500^{\mathrm{a}}$ & $0.471^{\mathrm{a}}$ & $0.385^{\mathrm{b}}$ & $0.500^{\mathrm{a}}$ & 0.027 \\
Gizzard (\%) & $3.625^{\mathrm{ab}}$ & $2.882^{\mathrm{b}}$ & $4.308^{\mathrm{a}}$ & $4.250^{\mathrm{a}}$ & 0.333 \\
Spleen (\%) & $0.188^{\mathrm{a}}$ & $0.200^{\mathrm{a}}$ & $0.231^{\mathrm{a}}$ & $0.083^{\mathrm{b}}$ & 0.032 \\
Heart (\%) & $0.438^{\mathrm{a}}$ & $0.353^{\mathrm{b}}$ & $0.385^{\mathrm{ab}}$ & $0.417^{\mathrm{a}}$ & 0.019 \\
\hline
\end{tabular}

Note: Means in the same row with different superscript differ significantly $(\mathrm{P}<0.05)$. R1= Feed supplemented with $0 \mathrm{~g} / \mathrm{kg}$ BW of PRA (control), R2= Feed supplemented with $1 \mathrm{~g} / \mathrm{kg}$ BW of PRA, R3= Feed supplemented with $2 \mathrm{~g} / \mathrm{kg}$ BW of PRA, R4= Feed supplemented with $3 \mathrm{~g} / \mathrm{kg}$ BW of PRA. 
sity effects on live performance, blood serum metabolite concentration, and carcass composition of broilers reared in thermoneutral and cycling ambient temperatures. Poult. Sci. 75: 1383-1392. http://dx.doi.org/10.3382/ps.0751383

Cao, J., P. R. Henry, R. Guo, R. A. Holwerda, J. P. Toth, R. D. Little, \& C. B. Ammerman. 2000. Chemical characteristics of ruminants. J. Anim. Sci. 78:2039-2054.

Esonu, B. O. 2006. Animal nutrition and feeding: A functional approach. Rukzeal and Rukson Association memory Press, Owerri, Nigeria.

Iwu, A. N., C. S. Ebere, I. P. Ogbuewu, I. F. Etuk, M. N. Opara, M. C. Uchegbu, I. C. Okoli, F. C. Iheukwumere, \& U. Herbert. 2013. Coconut shell ash as a mild agonist of reproductive organ development and sex hormones release in growing rabbits. J. Med. Sci. 13(7). DOI 10.3923/jms.2013

Kidd, M. T., P. R. Fertket, \& M. A. Qureshi. 1996. Zinc metabolism with reference to its role in immunity. World's Poult. Sci. J. 52: 309 - 310. http://dx.doi.org/10.1079/WPS19960022

Maleana, I. 1998. Wood ash as mineral supplement for growing lambs. Under Village Research 32: 191-194.

Nwogu, C.M., I. F. Etuk, \& I. C. Okoli. 2012. Ash from plantain stalk and root base as possible sources of organic minerals for poultry production. Int. J. Trop. Agric. Food Syst. 6:22-26.

Ochetim, S. 1988. Small - scale farming in Zambia: How to prepare local poultry feed. Misset. Int. Poultry 2: 36-37.

Odunsi, A. A., G. O. Farinu, J. O. Akinela, \& V. A. Togun. 1999. Growth, carcass characteristics and body composition of broiler chickens fed wild sun flower (Tithonica diversifolia) forage meal. Tropical Animal Production Investigation 2: 205-211.

Okoli, I. C., C. M. Nwogu, I. F. Etuk, A. A. Omede, I. P. Ogbuewu, N. O. Aladi, V. M. O. Okoro, M. N. Opara, C. Ezema, M. C. Uchegbu, B. U. Ekenyem, G. A. Anyanwu, N. J. Okeudo, A. B. I. Udedibie, \& F. N. Madubuike. 2013. Plantain ash enhances dietary mineral elements absorption in pullets. Iranian J. Appl. Anim. Sci. (In press).

Oluyemi J. A. \& Roberts F. A. 1979. Poultry Production in Warm Wet Climate. $2^{\text {nd }}$ ed. Spectrum Books Ltd. Ibadan, Nigeria.

Oso, A. O., A. A. Idowu, \& O. T. Niameh. 2011. Growth response, nutrient and mineral retention, bone mineralization and walking ability of broiler chickens fed with di- etary inclusion of various unconventional mineral sources. J. Anim. Physiol. Anim. Nutr. (Berl.) 95: 461-467. http:// dx.doi.org/10.1111/j.1439-0396.2010.01073.x

Salem, B. H., S. Abidi, H. P. S. Markkar, \& Z. A. Net. 2005 Wood ash treatment. A cost effective way to deactivate tannin in Acacia cyanophylla Foilage and to improve digestion by barbarine sheep. Anim. Feed Sci. Technol. 122: 93108. http://dx.doi.org/10.1016/j.anifeedsci.2005.04.013

SAS Institute. 1999. SAS/STAT User's Guide: Statistics. Version 8.00. SAS Inst. Inc.,Cary, NC.

Selema, M. D. \& M. E. Farago. 1996. Trace element concentrations in the fruits peels and trunks of Musa paradisiaca. Phytochemistry 42: 1523-1525. http://dx.doi.org/10.1016/00319422(96)00165-3

SON. 2003. Specification for poultry feeds. Nigerian Industrial Standards. N15259: 2003. Standard Organization of Nigeria. Abuja, Nigeria.

Steel, R. G. D. \& J. H. Torrie. 1995. Principles and Procedures of Statistics: A Biometrical Approach. $3^{\text {nd }}$ ed. McGraw-Hill Book Coy. Inc., New York.

Uchegbu, M. C., A. O. Ibekwe, I. P. Ogbuewu, H. O. Obikaonu, C. H. Nwaodu, \& I. C. Okoli. 2009a. Feed intake and growth rate by finisher broilers fed diets containing raw and cooked Napoleona imperialis seed meal. Revista Cientifica UDO Agricola 9: 1-4. http://dx.doi.org/10.3923/ ijps.2009.1162.1164

Uchegbu, M. C., N. O. Igbokwe, A. A. Omede, I. C. Ekwuagana, I. C. Okoli, \& B. O. Esonu. 2009b. Performance evaluation of some commercial broiler finisher rations sold in Nigeria. International Journal of Poultry Science 8: 1162-1164.

Uchegbu, M. C., I. C. Okoli, C. E. Anyanwu, E. B. Etuk, B. O. Esonu \& A. B. I. Udedibie. 2004. Performance, carcass and organ characteristics of finisher broilers fed graded levels of raw Napoleoana imperialis seed meal. Livestock Research for Rural Development 16(6). http://www.lrrd. org/lrrd16/6/uche16041.htm

Udedibie, A. B. I., O. J. Chukwurah, G. E. Enyenihi, H. O. Obikaonu, \& I. C. Okoli. 2012. The use of sun-dried cassava tuber meal, brewers' dried grains and palm oil to simulate maize in the diet of laying hens. Journal of Agricultural Technology 8: 1269-1276. 